\title{
An Autosomal Pericentric Inversion in Gallus domesticus
}

\author{
D. L. POLLOCK and N. S. FECHHEIMER (*) \\ School of Agriculture West Mains Road, Edinburgh EHg $3 J G, U . K$. \\ (*) Dept. of Dairy Science Ohio State, University Columbus, 43210 Ohio, U.S.A.
}

A pericentric inversion in the number two autosome was produced by sperm irradiation, and isolated in a line of birds. Morphology of the autosome changed from markedly submetacentric (arm ratio 0.58 ) to almost metacentric (arm ratio 0.80 ). Examination of pachytene cells revealed that no inversion loop was present but a non pairing segment was visible in some cells. Chiasmata counts at diakinesis suggested that the inversion caused a reduction of 0.6 chiasma (not yet tested statistically). Secondary spermatocyte metaphases showed a ratio of 0.5 for normal to inverted two autosomes, and genome imbalances were not detected.

Fertility levels in matings of heteromorphic males to normal females were normal and examination of metaphases from i 8 hour embryos showed a ratio of 0.5 for normal to heterozygous karyotypes, with no chromosome imbalances being detected.

\section{Molekulare Aspekte bei Chromosomenaberrationen}

\author{
M. FORSTER \\ Lehrstuhl für Tierzucht der Techn., \\ Universität München in 8050 Freising, Weihenstephan (R.F.A.)
}

Zunehmend vertrauter werden die optischen Darstellungen von Chromosomen-aberrationen, wenn leider auch meist nur mit lichtmikroskopischen Aufnahmen. Zum besseren Verständnis der Veränderungen des chromosomalen Materials ist jedoch eine molekulare Betrachtungsweise der Chromatinphysiologie erforderlich. Die Beschreibung der einzelnen Funktionselemente der Chromatinelementarfaser und der Metaphasenchromosomen ermoglicht Einblicke in die Mechanismen der Chromatinmetabolisierung und die daraus entstehenden Chromosomenaberrationen.

\section{Variability of banding patterns in chromosome F1 of the cat karyotype}

\author{
M. HAGELTORN \\ Department of Animal Genetics, Nutrition and Hygiene, \\ Royal Veterinary College, HVC, S-750 o7 Uppsala 7 (Sweden)
}

A striking polymorphic banding pattern of chromosome FI, one of the two $t$ pairs, was observed in a cat family. The family was brought to our attention because the dam continually gave rise to small litters and on one occasion two malformed kittens.

The broad light $\mathrm{G}$-banded segment was demonstrated to be either double sized $(q+)$ or completely missing $(q-)$. With the $Q$ and the $R$ techniques the "normal " and " + segments" did not fluoresce, or fluoresced very weakly, respectively, while with the $C$ technique the segment stained dark. Individuals with the chromosome combinations, $q q, q q+$ and $q+q-$, have been observed, all of which were phenotypically normal and apparently with normal fertility.

The nature of the polymorphic banding pattern and possible association to litter size and malformation:s are discussed.

\section{La chromatine Barr dans les cellules du sarcome de Stiker}

Doina PASCA et A. CARATZALI

Institut du contrôle des médicaments des animaux domestiques, Institut central de Biologie, Bucarest (Roumanie)

La maladie de STICKkr, sarcome vénérien du chien, est due à la greffe d'une cellule véhiculant un virus lors du contact sexuel ou dans des conditions expérimentales (cf. D. PASCA, Th. Méd. Vét., Bucarest, r972). Parmi les chromosomes de la cellule tumorale prédominent les dibran- 